\title{
Miranda
}

Revue pluridisciplinaire du monde anglophone /

Multidisciplinary peer-reviewed journal on the English-

speaking world

$12 \mid 2016$

Mapping gender. Old images ; new figures

\section{We'll dance}

(in memoriam David Bowie)

Nathalie Vincent-Arnaud

\section{(2) OpenEdition}

\section{Journals}

Electronic version

URL: http://journals.openedition.org/miranda/8540

DOI: $10.4000 /$ miranda.8540

ISSN: 2108-6559

\section{Publisher}

Université Toulouse - Jean Jaurès

\section{Electronic reference}

Nathalie Vincent-Arnaud, "We'll dance ", Miranda [Online], 12 | 2016, Online since 01 March 2016 connection on 16 February 2021. URL: http://journals.openedition.org/miranda/8540 ; DOI: https:// doi.org/10.4000/miranda.8540

This text was automatically generated on 16 February 2021

\section{(c) (†) $\ominus$

Miranda is licensed under a Creative Commons Attribution-NonCommercial-NoDerivatives 4.0 International License. 


\section{We'll dance}

(in memoriam David Bowie)

Nathalie Vincent-Arnaud

1 We'll dance

We'll dance away the fears, the tears, the lullabies

The monsters creeping by

Turning the scars to blues

We'll dance

We'll sing away the pains and the tongue-twisted lies

The darkness crawling in

And the wind growing wild

We'll dance

We'll just turn on the lights of weird hopes cast aside The people passing by

Putting on brand new smiles

We'll dance

Burning bright in disguise when the faces turn cold

Clinging to stories of old

of aliens, sores and dance halls

And we'll believe

(January 2016) 
INDEX

Mots-clés: Bowie, in memoriam

Keywords: Bowie, in memoriam

Subjects: Music

\section{AUTHORS}

NATHALIE VINCENT-ARNAUD

Professeur

Université de Toulouse 2-Jean Jaurès

nathalie.vincentarnaud@sfr.fr 